https://helda.helsinki.fi

\title{
Emotional roots of right-wing political populism
}

\section{Salmela, Mikko Erkki Matias}

2017-12

Salmela , M E M \& von Scheve , C 2017 , ' Emotional roots of right-wing political populism ' , Social Science Information, vol. 56 , no. 4 , pp. 567-595 . https://doi.org/10.1177/0539018417734419

http://hdl.handle.net/10138/229835

https://doi.org/10.1177/0539018417734419

cc_by_nc_nd

acceptedVersion

Downloaded from Helda, University of Helsinki institutional repository.

This is an electronic reprint of the original article.

This reprint may differ from the original in pagination and typographic detail.

Please cite the original version. 


\title{
EMOTIONAL ROOTS OF RIGHT-WING POLITICAL POPULISM
}

\author{
Mikko Salmela and Christian von Scheve
}

*** Article in press in Social Science Information $* * *$

\begin{abstract}
The rise of the radical populist right has been linked to fundamental socioeconomic changes fueled by globalization and economic deregulation. Yet, socioeconomic factors can hardly fully explain the rise of new right. We suggest that emotional processes that affect people's identities provide an additional explanation for the current popularity of the new radical right, not only among low- and medium-skilled workers, but also among the middle classes whose insecurities manifest as fears of not being able to live up to salient social identities and their constitutive values, and as shame about this actual or anticipated inability. This link between fear and shame is particularly salient in contemporary capitalist societies where responsibility for success and failure is increasingly individualized, and failure is stigmatized through unemployment, receiving welfare benefits, or labor migration. Under these conditions, we identify two psychological mechanisms behind the rise of the new populist right. The first mechanism of ressentiment explains how negative emotions -- fear and insecurity, in particular -- transform through repressed shame into anger, resentment, and hatred towards perceived "enemies" of the self and associated social groups, such as refugees, immigrants, the long-term unemployed, political and cultural elites, and the "mainstream" media. The second mechanism relates to the emotional distancing from social identities that inflict shame and other negative emotions, and instead promotes seeking meaning and self-esteem from aspects of identity perceived to be stable and to some extent exclusive, such as nationality, ethnicity, religion, language, and traditional gender roles.
\end{abstract}


Emotional roots of right-wing political populism

\section{Introduction}

Right-wing populist - nationalist, conservative, and anti-immigrant ${ }^{1}$ - political parties and social movements across Europe are widely judged to be a challenge to liberal and democratic societies. This is particularly evident when looking at the debates on refugees and asylum seekers that have dominated public discourse in Europe towards the end of 2015 and throughout 2016. Although there seems to be consensus that right-wing populist parties are detrimental to social cohesion and solidarity within and across European societies, understanding their success and the increasing numbers of supporters remain a largely unresolved task for the social sciences.

One particularly promising and influential approach at explaining this rise in "third wave" right-wing populism (after the first wave immediately after World War II and second upsurge in the 1960s and 1970s) seeks to connect it to fundamental social and economic changes that have taken place in the wake of modernization, globalization, and economic deregulation (Arzheimer, 2009; Beyme, 1988). These changes have transformed $20^{\text {th }}$ century industrial and nation-based capitalism into $21^{\text {st }}$ century post-industrial global capitalism with an increased mobility of jobs, capital, and people. Jobs have been relocated to places where factor prices yield the highest comparative advantage, leaving many low- and mediumskilled workers unemployed. Transnational mobility and the political destabilization of many African and Middle Eastern countries have promoted immigration both to and within Europe. Today, many immigrants are unemployed or work in low-income, low-status jobs that are eschewed by the native labor force. More than ever, Europe is faced not only with labor migration but also with large numbers of refugees and asylum seekers.

These transnational mobilities go hand in hand with substantial changes in the arrangements between economy and society. Increasing economic deregulation, globalization, and

\footnotetext{
${ }^{1}$ According to Mudde (2007), the core ideological features of populist radical right parties in Europe are nativism, authoritarianism, and populism. Nativism holds that "states should be inhabited exclusively by members of the native group ("the nation") and that non-native elements (persons and ideas) are fundamentally threatening to the homogenous nation-state" (Mudde, 2007: 22). Authoritarianism refers to "the belief in a strictly ordered society, in which infringements of authority are to be punished severely." (Mudde, 2007: 23). Populism "considers society to be ultimately separated into two homogeneous and antagonistic groups, "the pure people" versus "the corrupt elite"." (Mudde, 2007: 23). Extremism differs from populism by being openly anti-democratic in opposing political pluralism and the constitutional rights of minorities whereas populists are anti-democratic in spirit at most.
} 
Emotional roots of right-wing political populism

privatization have extended the principles of competition and market exchange to domains of life that have previously been governed by informal and embedded ties or reciprocal exchange. This, amongst other factors, has led to increasing social inequalities as well as decreasing solidarity and societal integration between social groups. With individualized careers and risks, employees increasingly need to become self-entrepreneurs, competing with each other for jobs and social recognition (Bröckling, 2016). Even those who have been able to maintain their jobs feel the pressure of an increased workload and flexibility - "a game of hire and fire with very few rules attached" (Bauman, 1998: 27). Although evidence is still missing, these structural changes are likely to have accelerated in the aftermath of the EU's financial crisis and the politics of austerity. Citizens most affected by these social and economic changes, such as blue-collar workers, the retired, the less educated, the selfemployed petite bourgeoisie and public sector bureaucrats have been identified as makingup the highest proportion of voters of right-wing parties (Berezin, 2009; Betz, 1994; Guibernau, 2013; Kriesi, 1999; Norris, 2005). The fact that the majority of these voters everywhere have been men suggests that the socio-economic changes fueled by globalization and economic deregulation have predominantly affected (white) men (e.g. Wodak, 2015).

These changes, however, cannot fully explain the attraction of right-wing populist parties, as several studies have pointed out (Eatwell, 2003; Flecker et al., 2007; Minkenberg, 2000; Mudde, 2007; Norris, 2005). To begin with, the structural account suggests a correlation between the proportion of immigrants and asylum seekers within a country and the success of right-wing populist parties. Even if this relation is found in some countries, such as Austria, Belgium, France, and Sweden, there are other countries where this correlation is absent. For instance, in Hungary, Finland, and Slovakia, right-wing populists have succeeded in elections despite the small number of immigrants and asylum seekers (until very recently) in those countries (Mudde, 2007). Also, attitudes against immigration and multiculturalism measured at the national level are only moderately correlated with the electoral success of populist right-wing parties across Europe. This correlation only exists at the individual level regarding voting behavior (Norris, 2005). 
Emotional roots of right-wing political populism

Second, there does not seem to be a robust association between unemployment levels and the popularity of right-wing parties within a country. Right-wing populist parties have been successful also in Northern and Central European countries, in which unemployment rates are below the OECD average, and welfare systems can compensate for those negatively affected by globalization and neoliberal policies. The Scandinavian countries, the Netherlands, Austria, and Switzerland are good examples in this respect (Swank and Betz, 2003). Moreover, many people have undergone the same socioeconomic changes without showing attraction to right-wing populism, even if there is some evidence that unemployment correlates with electoral success of the far right in countries with high immigration rates (Golder, 2003). Still for others, these changes have strengthened their socialist convictions or commitment to social vocational associations (Flecker et al., 2007).

Finally, populist right-wing parties do not derive their support entirely from people most negatively affected by globalization. Their voters are likely to also include those who profit from these developments, for example young entrepreneurs and professionals who identify with company goals as a consequence of their occupational advancement (Flecker et al., 2007). Even so, recent evidence suggests that neoliberal economic attitudes do not predict right-wing voting across European countries (Arzheimer, 2009).

Although structural approaches account for explaining a considerable amount of variation in right-wing voting behavior, they are also faced with inconsistencies and blind spots, for example regarding exceptional country cases. These shortcomings point to other, more psychological and attitudinal factors or collective mechanisms that mediate between structural changes and the success of right-wing parties (Mileti and Plomb, 2007; Minkenberg, 2000). Attitudes that motivate right-wing voting certainly include negative attitudes toward immigrants, in-group favoritism, perceptions of ethnic threat, political distrust, authoritarian personality traits and general political orientation as well as previous party preferences (see Lubbers et al., 2000; Werts et al., 2012). In summarizing existing research, some have suggested that anti-immigrant attitudes and political dissatisfaction are the most reliable predictors of right-wing electoral success (Lubbers and Scheepers, 2001; Lubbers et al., 2002). On the other hand, nationalist attitudes, social isolation, and protest motives only seem to play minor roles (Arzheimer, 2009; Werts et al., 2012). 
Taken together, structural and attitudinal accounts both justify the conjecture that subjective and intersubjective perceptions of threat and vulnerability are critical for understanding the success of right-wing populist parties. Even those who profit from contemporary social and economic developments may perceive themselves as being threatened by future economic blows or by various out-groups and minorities, maybe because they have witnessed the downfalls of others in societies characterized by a culture of fear (Furedi, 2007). "Therefore support patterns of the new radical right in the era of post-modernity should be interpreted as 'modernization losers' in a subjective sense", where this sense of vulnerability emerges from shrinking social and cultural capital rather than from actual victimization, as Minkenberg (2000: 182-183) points out.

Yet, the conditions and mechanisms underlying this "subjective sense" of perceptions of threat and vulnerability have hardly been explored. In this contribution we argue, based on recent theorizing and evidence, that affects and emotions play a critical role in generating this sense and in linking it to the structural and attitudinal precursors of the motivation to support populist right-wing parties. Perceptions of threat and vulnerability most likely also motivate support for left-wing populist parties, and we assume that the ensuing emotional dynamics related to these perceptions are different for right-wing and left-wing support, in fact being consequences of political mobilization strategies and mechanisms that distinguish between either one.

In this contribution, we primarily focus on the emotional dynamics of support for right-wing populist parties and are less interested in how these are distinct from the dynamics of leftwing populist support. Our theoretical and methodological approach is to combine insights from existing theorizing and research on the emotional dynamics underlying support for right-wing populist parties with more general theories of emotion in philosophy and the social sciences, in particular regarding the generation of emotions. These theories generally take a constructivist approach and include propositions on the psychological, social, and cultural determinants of different emotions that are to some extent generalizable across individuals and situations (henceforth referred to as "mechanisms"). Our aim is to show that these approaches to emotion can be fruitfully applied to better understand political 
Emotional roots of right-wing political populism

attitudes and behaviors, in particular support for populist parties. Our primary aim is to develop empirically informed theoretical insights and propositions that may contribute to the development of hypotheses and empirical research, for example regarding concrete differences in the emotional dynamics of left- and right-wing populism or the differences between specific political parties or national contexts.

To this end, we first review existing works that have highlighted the importance of different emotions for right-wing support, in particular anger and resentment as well as feelings of insecurity and powerlessness. We then argue that shame -- in particular repressed shame -is a central although often overlooked emotion accounting for support for specifically rightwing populist parties. In a third step, we introduce two mechanisms we consider critical in linking emotions to right-wing support: first, a social psychological mechanism that contributes to transforming shame into anger directed at those who are perceived as a threat to one's identity; and second, a macro-social mechanism that contributes to rendering occupational identities less salient when compared to identities based on ascriptive qualities, such as race, nationality, or ethnicity.

\section{Resentment and Ressentiment: The two classical roads to right-wing support}

Affects - emotions and feelings - play an obvious, yet somewhat neglected role in research on right-wing populism that has mainly been investigated from a "structure" rather than from an "agency" perspective (Demertzis, 2006; Eatwell, 2003). Emotions and feelings have an important role in perceptions and judgments of belonging to a group that is "winning" or "losing" in processes of modernization and globalization. A prominent theory regarding the success of third wave right-wing populist parties has emphasized the emotion of resentment or ressentiment (Betz, 2005; 1994), suggesting that electoral support for these parties mainly comes from those who are left behind and experience (a) fear and insecurity about their identity, work, and entire life; (b) alienation and displacement at the loss of social bonds (Scheff, 2000); or (c) disappointment and distrust in politics and the workings of democracy (see also Guibernau, 2013, 2010; Ignazi, 2003; Minkenberg, 2000). Likewise, emotions and feelings figure centrally in the rhetoric of populist right-wing populist parties that frame issues like immigration, national culture, and employment in terms of emotions like fear, 
Emotional roots of right-wing political populism

anxiety, anger, and feelings of powerlessness. Prospective right-wing voters are known to experience these emotions in these and related contexts and the open appeal to these very emotions is part and parcel of the populism of the new right (Laclau, 2005).

A key problem of this "resentment approach" is its relatively loose conception of the individual and collective mechanisms that mediate between macro-level socioeconomic and more micro-level attitudinal predictors in explaining support for right-wing parties. "Resentment" is a very general affective category under which, for instance, Betz (1994) discusses (a) distrust, alienation, discontent, cynicism, pessimism, insecurity, and feelings of powerlessness; (b) anger about perceived unjust or unfair treatment; and (c) hate as an intensification and/or temporal extension of resentment. Yet the very notion of resentment is ambiguous, and Betz's wavering between the English resentment and the French ressentiment is symptomatic of widespread conceptual confusion since both are quite different emotions with different social and psychological dynamics and implications.

While resentment is generally understood as a long-term affective attitude a person develops in response to another's insult, injury, or offence (Ben-Ze'ev, 2000; Meltzer and Musolf, 2002; Strawson, 1974), ressentiment in the technical sense - as introduced by Nietzsche and elaborated by Scheler (1994 [1915]) - emerges from negative emotions and affects such as envy, hatred, malice, or spite towards another person or persons in situations where one feels impotent to act on one of these emotions. These emotions are then "repressed" and "transformed" into passive resentment, hostility, or hatred towards the other. Moreover, ressentiment involves a hidden sense of powerlessness and self-disvalue in comparison with others. The main differences between resentment and ressentiment concern the sense of one's own powerlessness and the repression of other negative emotions that are involved in ressentiment but not in resentment. Therefore, we suggest that one needs to carefully distinguish between the two - resentment and ressentimentwhen investigating the emotional roots of right-wing populism.

In further developing his account, Betz (2005: 28) resolves this conceptual problem in favour of ressentiment, arguing that it "derives primarily from repeated experiences of individual weakness and powerlessness". However, he continues that "ressentiment is more than 
Emotional roots of right-wing political populism

merely a passive, impotent emotion; it always also engenders a desire for action; for radical change, which is thoroughly political..." in challenging the political and the cultural establishments (Betz, 2005: 28). Although this is an important clarification, it leaves open the involvement of other negative emotions that produce and maintain experiences of individual weakness and powerlessness in the "background" of ressentiment. Betz and other theorists have not been eager to venture into this question. Instead, they prefer to keep the affective background of ressentiment diffuse and wide. Yet, even if there is a link between responding with ressentiment to perceptions of defeat and right-wing support, we still know little about the mechanisms that may bring about this association (Berezin, 2009). In what follows, we attempt to identify some of these mechanisms.

Ressentiment theory, in our view, can be elaborated by explaining how ressentiment comes to occupy a central place in the motivational basis of the new radical right, i.e. for parties and movements such as the Austrian Freedom Party (FPÖ), the Finnish Finns Party (PS), the French National Front, the German Alternative für Deutschland (AfD), or the Progress Party $(F r P)$ in Norway. More specifically, we propose a social psychological mechanism that transforms certain negative emotions - in particular fear and insecurity - experienced in specific social circumstances (in our case, contemporary capitalist societies) into anger, resentment, and hatred. Whereas the existing literature mentions these emotions as more or less directly motivating support for both right- and left-wing populist parties, our account suggests that their close intertwining with shame -- in particular with repressed shame in right-wing populism and acknowledged shame in left-wing populism -- is characteristic for the emotional dynamics underlying support for populist parties in contemporary capitalist societies.

Fear of "Islamic terrorism", for example, clearly motivates support for radical right-wing parties that advocate cultural protectionism and restrictions on immigration directly, without the involvement of other mediating emotions. Likewise, outrage or resentment over bank bailouts or politics of austerity can directly motivate support for populist left-wing parties, as many have argued (e.g., Baumgarten, 2013; Benski and Langman, 2013; Davou and Demertzis, 2013; Perugorria and Tejerina, 2013; della Porta, 2015). Regardless of this direct influence, however, we suggest that many fears and insecurities prevalent in 
Emotional roots of right-wing political populism

contemporary market societies contribute to producing actual or anticipated shame that -when repressed -- transforms into anger and resentment, as suggested by psychoanalytically inspired sociological theories of emotion (Scheff, 1994; Turner, 2007). We assume that the likelihood for the repression of shame -- and hence also for the resulting anger and hatred -correlates closely with the structural determinants of support for right-wing populism outlined above and might thus be a mechanism that mediates between structural changes and the success of right-wing parties. A key tenet of Scheff's (1994) and Turner's (2007) theories is that anger and hatred that result from repressed shame seek to be directed away from the self. Therefore, those strategies and rhetorics are likely to be successful at harvesting political support that direct shame-induced anger and hatred at alleged "enemies" of the self and associated groups, such as refugees, immigrants, the long-term unemployed, political and cultural elites, and the "mainstream" media.

This proposed mechanism can therefore increase our understanding of why recent protests, in particular those against austerity politics and immigration, have been engrossed mainly by the radical right rather than the left that had benefited from citizens' dissatisfaction in previous decades. This is not to say, of course, that left-wing populism is not fueled by anger and resentment as well - but most likely not predominantly via repressed shame. This suggestion is supported by the different targets at which anger and resentment are strategically channeled by populist right- and left-wing parties.

Left-wing populists tend to blame neoliberal policies and the national and supra-national institutions (e.g., EU, IMF) enforcing policies that are suspected to increase injustice, inequality, and precariousness. This recruits emotions of indignation or anger that many might harbor on moral or ethical grounds. In contrast, right-wing populists' anger and resentment are targeted towards refugees, asylum seekers, the long-term unemployed as well as at ethnic, religious, and sexual minorities and "cultural elites". These emotions may also be rooted in perceptions of immoral or inappropriate behavior, but they are, so we argue, also driven by repressed shame because their targets likewise are perceived enemies of the precarious self. 
Emotional roots of right-wing political populism

Thus for instance the Greek right-wing extremist party Golden Dawn blamed a corrupt political establishment, immigration, and multiculturalism for the recent debt crisis that the party interpreted primarily as a national humiliation. In contrast, a local indignation movement and the radical left-wing populist party SYRIZA perceived this crisis as a structural flaw of capitalism and the austerity politics implemented as the solution to this crisis as morally outrageous because it drove large parts of the Greek society into precariousness (Sotirakopoulos \& Sotiropoulos 2013; Davou \& Demertzis 2013).

A related example is that left-wing populism has been more successful compared to rightwing populism in countries most severely affected by the 2008 financial crisis, for example Greece, Spain, and Portugal, where more radical austerity cuts were implemented than in countries that suffered less from the crisis. ${ }^{2}$ The fact that large segments of the population have been affected by austerity cuts in countries most severely hit by the crisis has given rise to a common awareness that individual citizens and selves cannot be blamed for losing their jobs, homes, or prospects of a secure life in consequence of cuts to salaries, pensions, and public services and increased costs of living (della Porta, 2015). Protesters are thus more likely to self-identify as aggrieved and humiliated by neoliberal policies and to direct blame at politics, politicians, and institutions perceived to be responsible for the situation instead of blaming the self. In contrast, citizens in countries less affected by this crisis are facing the consequences of neoliberal globalization and their own vulnerability in more individualized terms, which contributes to each individual accepting more responsibility for his or her actual or anticipated losses and precarious condition. This kind of responsibility attribution is further supported by a neoliberal citizenship regime (Wacquant, 2010; Mäkinen, 2016).

In this way, the proportion of citizens in a country affected by the consequences of neoliberal politics can be an important factor influencing either the acknowledgement or the repression of shame. The former type of shame holds significant emancipatory potential

\footnotetext{
${ }^{2}$ The popularity of Corbyn-style labor politics in United Kingdom may associate with the pronounced austerity politics implemented in the country during the recent conservative-liberal coalition and conservative governments even if it has not been directly involved with the Euro crisis (Clarke and Newman, 2012). However, it is important to observe that right-wing populism (UKIP) has become strong in the UK as well. Ireland is also an interesting case, because it was severely hit by the financial crisis but did not develop a prototypical populist party, neither on the right nor on the left end of the political spectrum. Instead, populist arguments have been on the rise in all of the existing parties (see the discussion in O'Malley \& FitzGibbon, 2015).
} 
Emotional roots of right-wing political populism

because it allows individuals to identify and establish bonds with others who feel the same for similar reasons. Awareness of this potential may contribute to the transformation of shame into humiliation that allows the aggrieved to blame others who are perceived to be responsible for their precarious situation. ${ }^{3}$ In contrast, those who blame themselves remain in the experience of (actual or anticipated) shame that, when repressed, transforms into anger and hatred politically channeled at minorities and out-groups.

These examples support the view that dissimilar emotional dynamics might be at play behind politically opposite branches of populism, partly because of different political strategies at channeling emotions, partly because structural determinants of right- and leftwing support affect the likelihood of the repression of shame.

\section{Emotions in explaining support for right-wing populism: General approaches}

In this section, we review existing research on those emotions that are presumed to motivate support for radical right-wing populism and also discuss the possibility to conceive of these emotions as intergroup emotions. Most studies capitalize on various negative emotions as motives for support for these parties, but in a rather general manner, without going into detail regarding specific emotions and their (inter-)relations. An exception towards a more systematic approach is the work by Flecker and colleagues (2007). They have identified two clusters of emotions that fuel the rise of the new radical right, anger and resentment on the one hand, and feelings of insecurity, powerlessness, and fear of déclassement, on the other hand.

\section{Anger and resentment}

Anger and resentment are perhaps the most visible emotions expressed or performed by radical right-wing populists and their supporters. Anger is the emotion of protest, and the identity and image of right-wing parties is firmly rooted in protest against the manifold

\footnotetext{
${ }^{3}$ On a different note, some philosophers argue that shame is a benign moral emotion that motivates individuals to amend flaws in the self revealed by shame (e.g., Deonna, Rodogno \& Teroni, 2012). We believe that insofar as shame has this kind of emancipatory potential, it associates with acknowledged shame alone because the repression of shame does not allow individuals to recognize what they are ashamed of.
} 
Emotional roots of right-wing political populism

changes we outlined above (Flesher Fominaya, 2014; Jasper, 2014; Van Stekelenburg and Klandermans, 2007; Van Zomeren et al., 2004). While anger is the generic emotion of being harmed or wronged, resentment is understood as specifically moral anger about being insulted, offended, or assaulted by another person or group. Some scholars (Ben-Ze'ev, 2000) claim that we resent actions rather than agents, while others (Barbalet, 1998) maintain that both, the perpetrators of the wrongs one suffers and those who benefit from these wrongdoings, are resented. Evidence discussed below supports the latter view.

Work-life with its implications for social status and living standards is an important source of anger and resentment in contemporary societies (Rackow et al., 2012). With individualized careers and risks, employees more and more become "entrepreneurs of the self" (Foucault) who compete with each other about various resources and social recognition. Even those who maintain their jobs in spite of the ubiquitous changes feel the pressures of increased workload and flexibility. Given the experience of work as an increasingly pitiless game of survival in which employees "fear that, in spite of hard work and sacrifices, they are not able to maintain or attain the standard of living and social status they have previously enjoyed or which they aspire to" (Flecker et al., 2007: 41-42), those who are perceived to avoid work or who live off the work of others, are seen as not deserving any welfare benefits. These "undeserving benefactors", usually including "the politicians on high and secure income, the refugees who are 'looked after by the state', and the long-term unemployed who allegedly do not want to work at all" (Flecker et al., 2007: 41-42), then become the targets of resentment. Importantly, this resentment can be experienced by both, those profiting and those suffering from the changes that characterize contemporary capitalist societies (see Flecker et al., 2007: 43). Instead of empathizing with citizens who are worse-off, people belonging to the former group often demand punishment of those whom they perceive to "under-perform" and to be "undeserving". The predicament of immigrants is especially grave, for if they are employed, they are accused of "stealing" jobs, whereas if they stay out of the labor force, they are resented for avoiding work or abusing welfare state benefits. With this kind of double bind, right-wing populists can present themselves and their clientele as victims in either case. 
Emotional roots of right-wing political populism

The divide between the unemployed and those in the labor force has become particularly salient in post-industrial societies where people's blame for the deterioration of work shifts to often faceless and intractable macroeconomic and structural developments, as is evident, for example in recent media discourse on the financial crisis (von Scheve et al., 2014). Consequently, the unemployed become a salient target group to be resented, in addition to the political elite that is blamed for merely standing by. The distinction between citizens in and out of employment is further reinforced by the view that individuals are themselves responsible for employment, regardless of job market conditions. This assumption helps the employed to maintain optimism and to repress the awareness that even those who internalize the competitive ethos of contemporary capitalism face the threat of unemployment. Berlant (2011) has characterized this counterproductive optimism, in which something you desire is an obstacle to your flourishing, as "cruel". This cruelty reinforces the need to maintain a sharp boundary between "us", the winners (so far), and "them", the losers who are blamed for their own condition (Bauman, 1998; Juntunen, 2014). In some sense, this interpretation is similar to Merton's (1963) concept of "anomia" that refers to (the experience of) a state of fundamental discrepancy between culturally promoted goals of life (e.g., having a well-paid job, a family, being a homeowner, etc.) and the means society provides (or can provide) to achieve these goals.

However, those in voluntary or involuntary unemployment are not the only targets of rightwing resentment. Right-wing populists and their sympathizers in on- and offline social networks frequently express resentment, hostility, and hatred towards ethnic, religious, and sexual minorities as well as "cultural elites" because they are regarded as threats to security, national identity, traditional institutions, gender roles, etc. (see Sakki and Pettersson, 2015; Wodak et al., 2013). Resentment is expressed towards perceived out-groups and others who are supposed to differ fundamentally regarding their values, attitudes, and practices, and who are thus construed as threats to collective identity and social status. Accordingly, it is difficult to locate particular wrongs or injustices that motivate or justify resentment towards these groups, even if right-wing populists are eager to present evidence of the overrepresentation of immigrants in crime statistics and to blame the "cultural elite" for protecting immigrants in the name of multiculturalism (Richards, 2013; Sakki and Pettersson, 2015). Yet, the intensity of this resentment and the mismatch between subjective 
Emotional roots of right-wing political populism

perceptions and empirical reality suggests that it may at least partly be understood as a kind of Schelerian ressentiment that would emerge from the repression of other negative emotions and involve a sense of powerlessness and inferiority in comparison with others. In this case, we need to understand what these other negative experiences are and where they come from. Although a mismatch between subjective perceptions and empirical reality is most likely also an outcome of discourse and biased portrayals on the internet, in social networks, and in some traditional media (Wodak et al., 2013), we suggest that Schelerian ressentiment plays an important role not to be neglected in explanations of right-wing populism.

\section{Insecurity, powerlessness, and fear of déclassement}

There is widespread agreement that increased insecurity and distrust are among the most important consequences of social and economic changes in the late $20^{\text {th }}$ and early $21^{\text {st }}$ century (Bauman, 2001, 2000). These changes also provide a fertile breeding ground of radical right-wing populism (Furedi, 2007; Kinnvall, 2013; Richards, 2013), as we will argue in more detail in the following. Insecurities in contemporary societies encompass existential and cultural, physical, environmental, and economic forms of uncertainty, "precarious living conditions and perceptions of profound ambiguity of a world that is hard to understand" as well as "calculable risks of one's market position" (Flecker et al., 2007: 44-45). Although the origins of uncertainty are social and global in nature, it is still experienced as an individual insecurity, in particular because globalization, neoliberal ideologies, and related developments have left individuals ever more on their own devices. Economic precariousness haunts many in capitalist societies and "the message is simple: everyone is potentially redundant or replaceable, and so everyone is vulnerable and any social position, however elevated and powerful it may seem now, is in the long run precarious" (Bauman, 2001: 52). With long-term precariousness, people tend to lose hope for a better future and to give up making plans for it, living instead in the concrete and immediate present. Bauman argues that this is "a rational response to the world in which one is compelled to treat the future as a threat, rather than as a shelter or a promised land" (Bauman, 2001: 52). In addition to hampering material living conditions, economic uncertainty hampers the construction and maintenance of vital social identities and "life projects" in contemporary 
Emotional roots of right-wing political populism

consumer societies. This also includes hampering of the freedom of choice regarding those identities and projects and adds insult of self-esteem to existing material injuries (Bauman, 1998).

In this view, perceptions of insecurity are more important than the actual stability of one's social position. People in relatively secure positions may feel threatened by the many changes brought about by globalization and modernization, now and in the future, since every blow to others "carries a message for all those who have been (for a time) spared, and prompts them to assess their own future by the severity of the likely sentence, not by the (unknown) length of its suspension" (Bauman, 2001: 51-52). These fears can affect all employees, not only low- or medium-skilled blue-collar workers whom these changes have affected most so far, but also skilled white-collar employees who can anticipate being the next in line. Along with fear of unemployment go fears of losing social status, established living standards, and of becoming part of a stigmatized group, such as the unemployed. Also, personal feelings of fear and injustice about old age in light of the dismantling of the welfare system are particularly salient. These fears often go hand in hand with an ideology of exclusion that requires that "in times of scarce resources there would have to be a guarantee that immigrants were not to profit at the expense of the majority population of the social welfare state" (Flecker et al., 2007: 57).

Importantly, while precariousness has recently extended to better educated and middle class workers, there is significant overrepresentation of low- and medium-skilled male workers among the inflicted. Their traditional jobs in industries, construction, transportation, and utilities are receding in post-industrial economies, whereas women are overrepresented in many of the more flourishing service sector jobs, in health, and in education. Even if men are still significantly advantaged in most contemporary labor markets, for example in terms of skills and wages, they are threatened inasmuch as their advantages remain linked to the currently receding jobs. Insecurities and fear of déclassement might therefore be more pronounced for men than for women in response to actual or anticipated job loss. ${ }^{4}$

\footnotetext{
${ }^{4}$ Traditionally, this gender bias has been explained by occupational identities that are thought to be more essential for men than for women, by work roles being more central to men and family roles being more central to women, and by the social norm of being employed that is supposed to count more for men than for
} 
People who feel threatened by the future tend to focus on the past (Weerdt et al., 2007). This often leads to nostalgic accounts contrasting the "good old days" with the aggravating present and an even more frightening future. Right-wing populists respond to this need by offering backwardly oriented utopias and historical narratives that glorify traditional communities with ethnic, national, and cultural homogeneity and victorious battles of those communities in the past. Heteronormative narratives with patriarchal values and gender roles, and family metaphors of nation are also prevalent in right-wing populist discourse both in Europe and US, and they associate with changing gender relations in these societies (Norocel, 2013; Wodak, 2015). The fact that such narratives are purposeful blends of fiction and reality is symptomatic of the need to sanitize the past to fit the present ideals of "pure" identities as well as to reinforce the image that the nation is once again "at war" with Others (Ahmed, 2004; Kinnvall, 2013; Mols and Jetten, 2014; Wodak and Forchtner, 2014). Thus, when these reactionary ideals and narratives are applied to the present, as for instance in the right-wing nationalist ideology of "ethnopluralism", they become justifications for resisting multiculturalism in the name of protecting ethnic and cultural differences by avoiding their "mixing" with each other. Even if this proposal is covered in a rhetoric of tolerance, its actual intolerance betrays an underlying fear and insecurity, for there is ample evidence for an association of intolerance and insecurity (Weerdt et al., 2007).

\section{Intergroup emotions}

Although anger and resentment as well as feelings of insecurity and powerlessness are usually discussed in broader social and cultural contexts, they are primarily understood as individual emotional phenomena. In complementing these views, we suggest that these feelings and emotions typically have both individual and collective instances that are directly implicated in motivating collective action and mobilization. Social psychological theorizing on intergroup emotions is particularly relevant in understanding how anger and resentment as outcomes of repressed shame become directed at perceived out-groups and how they translate into (collective) action and mobilization towards these groups. Although the

women (e.g., Newman 1998). However, as Lane (2011) and others suggest, these gendered identities, roles, and norms are most likely changing in the 21st century, and empirical studies find only moderate evidence that men are indeed more negatively affected by unemployment in terms of stress and well-being than women (e.g., Clark et al., 2008). 
Emotional roots of right-wing political populism

evidence supporting these theories is not immediately related to populist political parties, rendering their status tentative and somewhat speculative for our argument, we nevertheless think that they can help in making sense of certain strategies of right-wing populist parties and in assessing their emotional consequences.

For example, Intergroup Emotions Theory (Smith and Mackie, 2015) argues that many emotions are experienced because we identify with a social group or collective. In contrast to purely individual emotions, intergroup emotions arise because one's social identity and the concerns and goals of the group with which one identifies are made salient in a specific context. Whenever people tend to self-categorize as members of a particular group (from work teams, associations, to social categories such as gender, ethnicity or nationality), the events can be appraised not only based on one's personal concerns, but regarding the broader concerns of the group. This might lead to cases in which emotions are experienced "even if the event has absolutely no personal impact on the individual" (Smith and Mackie, 2015: 2). Intergroup emotions have been suggested to be particularly relevant in contexts involving conflict, competition, social comparison, or cleavages regarding culture and identity. They seem to be most frequently aimed at outgroups that are perceived as threats, for example anger and resentment regarding immigrants, homosexuals, or religious minorities. But intergroup emotions are likewise directed at the ingroup, for instance in cases of pride and joy. In this sense, right-wing populist parties and movements often engage in strategies of making religious or nationalist identities salient in a particular context and/or of discursively attributing emotions to their supporters. Claims such as "We as the German people feel offended by certain religious practices of the Muslim population" are a case at hand that combines both, the making salient of a group identity and the attribution of a corresponding emotion to the ingroup. Moreover, as Moons and colleagues (2009) have argued, groups also establish norms on how members should feel regarding certain issues or events.

Attributions of responsibility and blame that are based on in-group vs. out-group distinctions are also well established in the literature on scapegoating (e.g., Douglas, 1995). Groups that are scapegoated by right-wing populist parties are usually negatively stereotyped and prejudiced minorities to which blame for the in-group members' unwanted and undeserving 
Emotional roots of right-wing political populism

situation is directed. This sets the right-wing populist strategies and emotional dynamics apart from the left-wing counterpart, where we hardly see the blaming of prejudiced minorities, but in contrast the charging of those who wield economic and political power.

Anger and resentment as emotions that reflect group affiliations and dynamics may contribute to our understanding of support for right-wing populist parties because they - like other emotions - include strong motivational tendencies. In contrast to purely "individual" emotions, the motivational tendencies of intergroup emotions are often translated into corresponding actions through different channels and modalities, because it is difficult for an individual to directly act upon an entire out-group. Of course, violence, racism, and discrimination against individual members of perceived out-groups constitute possible and empirically observable courses of action, but the sharing, negotiation, and reinforcement of intergroup emotions via social media seems to be a more frequent form of collective action. Likewise, social media provide fora for discussing and initiating more "traditional" forms of collective action, such as protests and demonstrations. Supporting populist parties, through voting and membership, certainly is one of those forms and might be experienced as providing gratification and relief from negative emotions.

\section{Shame, an invisible emotion in theories on the new radical right}

Although anger, ressentiment, and feelings of insecurity and powerlessness certainly are important predictors of support for right-wing populism, we suggest that one of the most intricate and important emotions is neglected in current research, probably because it is rarely reported in interviews with informants - shame. The reason for this is that shame has strong negative experiential qualities and implications for the individual who often represses shame rather than consciously experiences it. Nevertheless, shame is implicated indirectly in the literature on right-wing populism and extremism in several ways that strongly suggest its involvement. We will first highlight indirect references to shame in this research, and then go on to analyze shame, its repression and transmutation into anger and resentment. 
Emotional roots of right-wing political populism

First, shame is involved in the fear of déclassement, the loss of social status, as an anticipated emotion. Anticipated shame may not be as intense as actual shame, but it closely resembles it in its unpleasantness and negative implications for the self. This is because it signals an expected loss, brought to the present in anticipation, rather than the mere threat or the possibility of a loss or social exclusion (Ahmed, 2004; Barbalet and Demertzis, 2013; Miceli and Castelfranchi, 2015; Neckel, 1991). The more insecure individuals feel about their ability to maintain their social status and standards of living, the more they come to anticipate the negative consequences that follow if they were actually incapable of doing so. Given relatively uncertain job prospects, many have experienced unemployment and only a few can feel exempt from these fears. The more there is to lose, the more vivid the fears of anticipated losses of status and standards of living become, and the more substantial the anticipated shame about these losses, in particular because responsibility for these losses has become strongly individualized (Sennett, 1998).

The threats of precarization or déclassement seem to be more important politically than actual déclassement, mostly because the electorate of the new radical right does not primarily consist of those most negatively affected by globalization and individualization, such as the long-term unemployed and those on welfare benefits (Eatwell, 2003; Mudde, 2007). Minkenberg (2000: 187) observes that voters of the new right-wing parties "can be characterized as the second-to-last fifth of postmodern society, a stratum which is rather secure but objectively can still lose something". People in this segment of society are aware of their position and of the efforts needed to keep them above the very bottom of society. However, the threat of precarization may extend more broadly in contemporary Western societies, including the middle-classes for whom downsizings, restructuring, and privatization can have grave consequences that were previously confined to the working classes (Sennett, 1998; see Mau, 2015, for an in depth discussion of this issue). ${ }^{5}$ An alarming piece of evidence of precarization that cuts through the entire society is a recent finding that

\footnotetext{
${ }^{5}$ The classic argument about the role of middle class in the emergence of right-wing radicalism is from Lipset (1963). He suggests that classic fascism was a movement of the propertied middle classes who used to support liberalism but turned away from it during the Great Depression, especially in Germany that suffered from it most. In his conclusion about the social bases of fascism, Lipset writes that extremist movements were supported by "those who for some reason or other had failed to make a success in their business or occupation, and those who had lost their social status or were in danger of losing it." (Lipset 1963: 178) Lipset does not analyze the role of shame in the middle class conversion from liberalism to fascism however.
} 
Emotional roots of right-wing political populism

$47 \%$ of Americans would have trouble finding $\$ 400$ to pay for an emergency. This standing financial insecurity is a secret source of shame and humiliation for many middle-class Americans, as the journalist Neal Gabler points out in his May 2016 cover story in The Atlantic, and as such, a possible factor behind the success of both right- and left-wing populist candidates -- Donald Trump and Bernie Sanders, respectively -- in the 2016 American presidential primary elections, as well as behind Donald Trump's success in the presidential elections. Hence, a common denominator for all social classes affected by precarization is their vulnerability to significant losses, both economically and socially, and their fears of losing their job, social position, and standards of living.

These losses, then, are intimately related to stigma, as conceptualized by Goffman (1963) and linked to shame by Lewis (1995) and Walker (2014). Although shame is often repressed and can thus hardly be focused on (see below), the stigma usually refers to some trait or characteristic that is publicly visible and observable. Because the stigma at the same time involves a lack of some sort or quality that is otherwise present in individuals and widely valued, stigmata are intimately linked to experiences of shame. Lewis (1995: 205-206) argues that shame, like guilt or pride, can (but need not) be elicited and experienced in private settings when one realizes failure to live up to certain social or moral standards or to those standards that are attributed to the self. Hence, stigma "may differ from other elicitors of shame and guilt, in part because it is a social appearance factor. The degree to which the stigma is socially apparent is the degree to which one must negotiate the issue of blame, not only for one's self but between one's self and the other who is witness to the stigma. Stigmatization is a much more powerful elicitor of shame and guilt in that it requires a negotiation not only between one's self and one's attributions, but between one's self and the attributions of others" (Lewis, 1995: 207).

Another attitude often attributed to those at the bottom of society is the loss of self-esteem (Bauman, 1998; Guibernau, 2013). Self-esteem is hardly ever analyzed in these contexts, but shame is obviously related to its loss, either constitutively or causally. Deonna, Rodogno and Teroni (2012: 87) argue that "shame is not simply a blow to self-esteem" but still "consists in an evaluation of oneself as degraded or worthless", where this worthlessness emerges from perceived inability to live up to one's core values (see also Rawls, 1971). Sometimes, shame 
Emotional roots of right-wing political populism

can also be felt vicariously if members of family or close friends are subjected to this predicament. People who find themselves worthless or redundant in contemporary societies, for instance due to unemployment and/or lack of relevant social and cultural capital, may experience shame, especially if the constitutive values of their salient social identities derive from more affluent times and are therefore unattainable to them in their present situation. Loss of self-esteem is also more consequential if it is global rather than specific, affecting several social roles and identities of a person rather than only some of them (Cast and Burke, 2002; Hoelter, 1986). Unfortunately, these losses often go together in contemporary consumer societies where economic capital is important for maintaining several social identities.

Finally, there is some evidence suggesting that people who are receptive to right-wing political ideologies tend to attribute the causes of their negative affects to themselves and to rely only on themselves in coping with negative events. Flecker and colleagues (2007: 46) point out that individualistic psychological coping strategies "on the one hand enhance work ethics and achievement orientation and, on the other, increase the fear of failure and the perceived risk". Strict work ethic, self-blame, and competitiveness link with high shameproneness when individuals do not meet their standards or fail in competition as the blame for these failures is attributed to the self. And as stated earlier, fear of failure of not being able to live up to one's core values attributed to the self already elicits anticipated shame. ${ }^{6}$

\section{Shame, social identities, and anger}

Shame, humiliation, and guilt are emotions directed at core conceptions of the self. Of these three emotions, shame is widely considered the most painful, since it attacks the self instead of focusing on rather specific actions, as in guilt, or on being the victim of demeaning and undeserved treatment, as in humiliation (Deonna, Rodogno and Teroni, 2012; Zahavi, 2012).

\footnotetext{
${ }^{6}$ Yet another indication of the involvement of shame among right-wing populists relates to their tendency to attribute shame to others, such as to the leading politicians of their country. Thus, for instance, the right-wing populist Finns Party candidates characterized Finnish politics in EU during the parliamentary election campaign in 2011 as crawling ("nöyristely"), stooping ("kyyristely"), and toading ("mielistely") (Vares \& Railo, 2011). Interestingly, these submissive behaviors can be seen as manifestations of shame in the presence of a higher status authority (Fessler, 2007). Therefore, it is possible that part of the shame attributed to others is projected from repressed experiences of shame in accordance with Clore \& Gasper's (1999) emotion misattribution hypothesis.
} 
Emotional roots of right-wing political populism

Still, humiliation and shame are linked to one another: If a person starts blaming him- or herself for being humiliated, for instance while registering for welfare benefits or being subjected to seemingly pointless job-seeking measures, humiliation turns into shame instead.

According to Deonna and colleagues (2012), shame is felt in response to our incapacity to live up to, or more precisely, to even minimally exemplify in behavior, our core value or values - many of which are shared with others as we want to point out. Social scientists as well as many philosophers stress the social nature of shame, claiming that it is felt about failures to meet others' normative expectations or standards, whatever they are, in the face of a real or imagined audience (Calhoun, 2004; Cooley, 1964; Scheff, 1994; Tangney and Dearing, 2002; Wollheim, 1999). In contrast, Deonna and associates (2012) argue that shame is centrally about the incapacity to (even minimally) exemplify one's commitment to a selfrelevant value in corresponding behavior. Therefore, shame is felt primarily in one's own eyes rather than in the eyes of others.

We believe that both of these views are partially correct and partially inadequate: shame is originally and typically a social emotion that signals a threat to social bonds, even if it can be felt as a consequence of violations against one's core values as well. The values and norms against which we evaluate the self negatively in instances of shame are neither exclusively our personal values nor the values of others. Instead, these values are both our own in the sense of being endorsed and internalized and they are shared with others, and we are aware of this sharing. Thus, we do not - or at least need not - feel ashamed of violations of values or norms that we do not endorse. In this respect, shame is autonomous (Zahavi, 2012).

However, as fundamentally social beings, we share most of our self-relevant values with others, and this social sharing often is a constitutive part of our social identities; hence, most values are shared by default (see also Von Scheve, 2015). ${ }^{7}$ This adds to the importance of

\footnotetext{
${ }^{7}$ Shared values that are constitutive of personally significant social identities differ from what Deonna et al. (2012: 138) characterize as "self-relevant values that concern the way we appear to others". The reason is that when we fail to exemplify a value constitutive of a social identity, this is not merely a matter of appearance to others but something that undermines our having that social identity. This in turn may have dire consequences for our social recognition as a quote from Goffman (1963: 27) illustrates: "How hard and humiliating it is to bear the name of an unemployed man. When I go out, I cast down my eyes because I feel myself wholly
} 
Emotional roots of right-wing political populism

being able to live up to these values. They are decisive for the recognition of our social identity as well as for the painful experience that results from our incapacity to adhere to these values and from the anticipated rejection and disdain of others if they witness this incapacity. This renders our failures and the shame about these failures social - even if shame is felt in private.

Following the psychoanalyst Lewis (1971), Scheff (1994) and Turner (2007) have argued that shame is often repressed due to its painfulness and negative implications for the self. Lewis distinguishes between conscious and denied shame where the latter has two types, overt and bypassed shame. In overt shame, the affect is available to consciousness but the subject either cannot or is not willing to identify it. In bypassed case, the affect underlying shame is unavailable to the subject. Even if denied shame is not experienced as shame, it can be felt as some emotion, and here psychoanalytic defense mechanisms such as displacement, projection, and attribution enter the picture. Following Lewis, Turner and Scheff suggest that denied or repressed shame does not disappear, but persists, becomes more intensive, and transforms into anger. This is when the initial self-blame of shame turns against others. In this way, psychodynamic processes change both the emotion type (from shame to anger) and its intentional object (from self to other), with the purpose of protecting the vulnerable self. This mechanism is similar to Scheler's ressentiment because the repression and transmutation of negative emotions and a shift in their intentional directedness are central to that concept as well. ${ }^{8}$ Turner (2007) makes a more precise suggestion on how this transformation actually works. He proposes that shame consists of three more basic emotions: sadness, anger at self, and fear about consequences to the self. When shame is repressed, only anger is felt, not directed at self, but as diffuse, ready to be targeted to "enemies" of the self and one's social identity. This is indeed a speculative hypothesis, but empirical findings that shame decreases empathy towards others are consistent with it (Tangney and Dearing, 2002).

inferior. When I go along the street, it seems to me that I can't be compared with an average citizen, that everybody is pointing at me with his finger. I instinctively avoid meeting any-one. Former acquaintances and friends of better times are no longer so cordial. They greet me indifferently when we meet. They no longer offer me a cigarette and their eyes seem to say, 'You are not worth it, you don't work'."

${ }^{8}$ Scheler (1994) does not discuss shame among the emotions that give rise to ressentiment. However, shame can be seen to be implicated in his account in feelings of inferiority that we experience when comparing ourselves negatively with others in the context of some important shared value. 
Turner remarks that people who fail to meet social and cultural expectations in several domains are more susceptible to shame than individuals successfully meeting these expectations. Moreover, "authority structures, per se, are shame-generating machines, and when coupled with the unequal distribution of valued resources, they increase the likelihood that large numbers of individuals will not meet expectations for resources - income from jobs, prestige from educational credentials that give access to money and power, love from family, or power from unions or political parties" (Turner, 2007: 520-521). Shame in different domains crops up, and when repressed, is intensified and "transmuted into righteous anger [with victim narratives] and desires for vengeance, and displaced onto actions of enemies to the broader social identity" (Turner, 2007: 518).

Importantly, repression makes it difficult for the subject to recognize the contexts in which shame emerged. Therefore, "the structures that originally generated negative emotional arousal are frequently not the targets of external attributions" (Turner, 2007: 521, original italics). Another reason for the invisibility of structures are ideologies such as competitive individualism that justify the unequal distribution of resources in different institutional domains. When these ideologies are taken for granted, the contribution of social structures to the shame-producing distribution of resources remains invisible. Turner remarks that once "shame is repressed, it can be manipulated by those with an interest in deflecting this anger onto chosen targets; typically this manipulation involves the symbols of one social identity and juxtaposes this identity through narratives about the evils of another social category or social identity" (Turner, 2007: 521-522).

Turner purports to explain instances of extreme violence such as genocides with this mechanism, but it is likely to operate in less consequential contexts as well. These may include the rhetoric of right-wing populist parties that deflects anger resulting from repressed individual shame towards political and cultural elites, immigrants, and the longterm unemployed rather than at globalization and economic liberalization as causes of events that provoke individual shame in the first place. ${ }^{9}$ At the same time, the collective

\footnotetext{
${ }^{9}$ Thus Mudde (2007: 197) remarks that "while issues like mass migration and the decreasing sovereignty of their nation are at the core of these [radical populist] parties' propaganda, they are seldom linked to the process of globalization".
} 
Emotional roots of right-wing political populism

anger of individuals becomes an affective "glue" that aligns them to a social collective (Ahmed, 2004). Positive collective emotions such as pride and joy felt in ritualistic encounters of the like-minded are also important in reinforcing social identities and group solidarity, as Turner (2007) point outs. Right-wing groups' defiant collective actions may also feed into empowerment and a sense of pride in the notoriety that emerges from a feeling of having the power to shock and dominate others or make them afraid, as is known from the literature on gangs, hooligans, and skinheads (Densley, 2013). Also, social media, blogs, and discussion forums offer venues for cultivating positive collective emotions as they allow people to develop and reinforce their ideas often anonymously and without critical voices (Malmqvist, unpublished; Sakki and Pettersson, 2015). However, insofar as collective pride in a social identity emerges from repressed individual shame, this pride may share some features that Tracy and Robins $(2007,2004)$ have associated with hubristic individual pride, namely narcissistic self-aggrandizement and antisocial behavior. Indeed, hubristic collective pride (Sullivan, 2014) and collective narcissism (Golec de Zavala et al., 2009) have been associated with prejudice and hostility towards outgroups, the latter also with low implicit group esteem. These features resemble Scheler's ressentiment at the individual level.

Given the potentially gendered nature of insecurities and fear of déclassement one might also suspect gender differences in the dynamics of repressed shame and its manifestation, even if Scheff and Turner do not discuss this possibility. However, the expression of anger is much more socially acceptable for men than women, and therefore, it is possible that repressed shame may manifest in different ways for women. Many right-wing populist parties had or have female leaders (e.g., the Danish People's Party, the German AfD, or the French Front National), and these parties have attracted female voters by presenting themselves as protectors of women's rights against the dangers allegedly posed by Islam. Still, many controversies, such as the Burqa or headscarf debates, are not primarily about women's rights, either Muslim or non-Muslim. Instead, a gendered argumentation is employed for exclusionary, nativist body politics against non-white, non-Christian ethnic communities in general, as Wodak $(2015,163)$ observes. Here we see a more indirect, rhetorically protective, aggression against generic "Others" than in direct targeting of alleged "enemies" of the self with anger, which might - on a speculative account - be more appealing to female than to male voters. 
Finally, there are some reasons to assume that shame is particularly salient in contemporary Western societies. The reason for this is that shame seems to be one of the "master emotions" (Scheff and Retzinger, 2000) of the neoliberal economic order. First, competition has become the main principle of distributing goods and services in many domains of social life (see above). According to Bauman (2001), a new "life politics" has brought a spirit of consumerism and pleasure principle to interpersonal relations that come with inbuilt and implicit "until-further-notice" and "withdrawal-at-will" clauses. Accordingly, it has become important for individuals to look after their exchange or market value. This value, however, is inherently precarious and therefore liable to produce experiences of worthlessness, marginalization, dispensability, fear, and frustration (Mäkinen, 2012). Importantly, different skills and capacities are required for exchange value in different social roles and identities: at work as an employee and a colleague, at home as a spouse, lover, and parent, and so on - all this both on-line and off-line. Insofar as the subject perceives the value of his or her self as depending on successful performances and/or self-presentation in all of these domains, this value becomes highly contingent and volatile. And since the individual is primarily responsible for success and failure in contemporary market societies, shame about the incapacity of "being the right kind of person" in different contexts can hardly be averted but only repressed. In general, the more domains of life in a society operate on the principles of competition, the more chances there are for failing to live up to the constitutive values of one's salient personal and social identities, and, consequently, for shame about this actual or anticipated incapacity. ${ }^{10}$

\section{Shame and the transformation of social identities}

The previous section introduced the argument that repressed shame transforms into anger that is targeted against opponents to one's social identity. This argument contained the idea that projection is a way of protecting the vulnerable self from shame by redirecting it outward. However, there is a second mechanism that may guide our understanding of why

\footnotetext{
${ }^{10}$ In a like manner, Scheler emphasized competition as a breeding ground of ressentiment, arguing that it is "strongest in a society like ours where approximately equal rights (political and otherwise) or formal social equality, publicly recognized, go hand in hand with wide factual differences in power, property, and education" (Scheler, 1994: 33). Our societies are once again, with the dismantling of welfare state, becoming similar to that of Scheler in which welfare state did not yet exist.
} 
Emotional roots of right-wing political populism

certain social identities become salient and why specific groups are construed as opposing outgroups. Individuals can distance themselves emotionally from those social identities that frequently evoke shame and other negative feelings such as fear, powerlessness, worthlessness, vulnerability, and so on. Shame-prone social identities become precarious, whereas social identities that seem to be beyond shame become increasingly more attractive.

In contemporary capitalist societies, those social identities that are based on resources that are allocated according to the principles of competition, are inherently shame-prone and therefore liable to alienation, particularly for people already occupying precarious positions. These social identities include occupational identities that in modernity were steady and consistent, and, as such, were central building blocks of publicly recognized and approved social identities (Bauman, 1998; Beck, 2000; Sennett, 1998). Today, the occupational identities of low- and medium skilled blue-collar workers who have largely lost their trust in trade unions as protectors of their interests seem to be especially vulnerable. Likewise, the identities of white-collar workers whose employers in both public and private sectors face pressures to cut expenditures are increasingly at risk.

Indeed, in flexible labor markets where seamless working careers have rather become an exception, it makes little sense to develop strong emotional attachments and commitments to an occupational identity - even if employers encourage or even demand this in the age of emotional capitalism (IIlouz, 2007). Instead, social identities that do not involve competition such as nationality, ethnicity, language, religion, and gender become more and more attractive as sources of meaning, self-esteem, and efficacy. These are also social identities in which solidarity and belonging with other group members can still be experienced in the framework of shared concerns, emotions, and meanings, unlike in the context of those social identities where individuals compete with one another.

The weakening of workers' mutual solidarity as well as of the power of their trade unions in combination with the precariousness of occupational identities hampers the mobilization of the traditional left and benefits the new radical right that attracts voters with allegedly "natural" and "stable" social identities at times in which other social identities are 
Emotional roots of right-wing political populism

experienced to be insecure and in constant flux. These stable identities appear less contingent and less demanding than others based on a combination of efforts, dedication, and luck, such as having a continuous successful working career. Taking pride in the ascriptive aspects of one's identity such as ethnicity, national culture, or gender - in general what one already is or has - is far less demanding and complicated than taking pride in what one has achieved, for the latter kind of pride requires constant efforts with increasingly uncertain chances of success. Insofar as there is competition at this level as well, individuals can identify with their representatives such as national teams in sports who are competing for the entire group. Stable social categories may become attractive as a kind of bedrock onto which one can fall back if the other, more contingently rewarding social identities fail to yield positive experiences in support of the self. This may explain the popularity of rightwing populism both among the 'losers' and some 'winners' of contemporary neoliberal capitalism. For those in disadvantaged positions, the appeal of stable social identities is obvious. But their appeal is also evident for those who profit from globalization and economic liberalization because they are aware of the precariousness of contemporary social life as we have argued above.

Politically, the emergence of identity and value issues in national politics coincides with a new consensus over neoliberal economic policies and the depoliticization of the economy. Social Democrats across Europe willingly adopted the "Third Way" of Anthony Giddens and Tony Blair as - what they saw - a necessary modernization of the Left in an era of globalization and individualization, thus giving rise to an unprecedented convergence in conservative and market-oriented economic policies. Tensions over economic (re)distribution and fairness have remained, and even increased over the last decades, but since they are demobilized in party politics, confrontations on moral and cultural issues have become salient in ideological and political demarcations. This dissolution of traditional class politics explains, at least in part, the odd companionship of working class and (especially lesser educated) middle class voters in the constituency of right-wing populist parties (Marsdal, 2013).

Neoliberalism strikes back: no escape from shame 
Emotional roots of right-wing political populism

Radical right-wing populism does not offer its adherents and sympathizers escape from the anxieties of post-industrial capitalism. The reason for this predicament is that the distinction between economically valuable and redundant citizens that the right-wing populists employ in their criticism of non-Western immigrants, refugees, and asylum seekers emerges from a neoliberal view on ideal citizenship that can be applied to everyone, irrespective of nationality and ethnicity. Thus the resented "underclass" includes the domestic poor along with other "economically irresponsible" subgroups who are perceived to live off the work of the "economically responsible" others (Bauman, 1998; Wacquant, 2010). Nationality and ethnicity are irrelevant here as native citizens who live off unemployment and other public benefits are blamed as free riders in the same way as refugees and asylum seekers (Juntunen, 2014; Mäkinen, 2013).

Right-wing populist parties started in Western Europe in the 1980's as adherents of neoliberalism, demanding dismantling of the welfare state, privatization, and the lowering of taxes. However, already in the 1990's, most of these parties moved to welfare chauvinism, demanding restriction of welfare benefits to the "own people" at the expense of "aliens": immigrants, refugees, and asylum seekers (Betz, 1994; Guibernau, 2013; Mudde, 2007). The argument is that, especially during the recent crises, welfare state benefits can be sustained at the required level only by prioritizing, and here - as populist right-wing parties argue native citizens should be privileged over others. Nevertheless, the neoliberal heritage of right-wing populism can be seen in views that restrict the native beneficiaries of the welfare state mainly to such groups as pensioners and those in bad health. Thus, welfare benefits for the (especially long term) unemployed may not be an integral part of a right-wing populist welfare state. Arguably, demands of cutting unemployment benefits or making them conditional on unpaid work have more support in traditional right-wing parties than in the new populist right. However, neoliberal sentiments about unemployment are shared even more widely in Western societies as it is commonly regarded as shameful and stigmatizing by both, the employed and the unemployed (Juntunen, 2014; Starrin, 2013).

A neoliberal attitude toward unemployment and other welfare benefits puts workers in a precarious job market into a difficult position. If being unemployed and taking unemployment benefits are blamed as being shameful, then there is no escape from shame, 
Emotional roots of right-wing political populism

except by staying employed, on whatever conditions. However, due to the precariousness of contemporary working life, staying employed is not entirely up to most of us. Therefore, shame remains in our lives, either as present reality, or as an anticipated future scenario. In this situation, compensatory welfare state benefits to those who do not profit from globalization and liberalization may remain psychologically ineffective insofar as their beneficiaries view their predicament as shameful and stigmatizing anyway.

This may offer a partial explanation to the paradox of why right-wing populist parties have succeeded so well even in relatively affluent and traditionally egalitarian Northern and Central European countries where income differences between the rich and the poor have increased during recent years (Guibernau, 2013; Swank and Betz, 2003). Even if these welfare states are still rather egalitarian in the context of other OECD countries, the increasing precariousness of working life may have been particularly consequential in these countries whose Protestant cultural heritage emphasizes the relevance of work and employment for social identity (Beck, 2000). Also, against the background of traditional egalitarianism, the relative loss of income, standards of living, and social status in comparison to the previous situation may elicit shame and anger among the actual and potential losers of this development, making them receptive to the affectively loaded messages of right-wing populism.

\section{Conclusion}

The findings referred above clearly emphasize the importance of policies directed at reducing feelings of insecurity and injustice through concrete measures of providing secure and stable employment and income resulting in satisfactory living conditions and subjectively meaningful integration into society. Experience in various countries has shown that not tackling the underlying problems but asking for tolerance and political correctness instead has contributed to the success of right-wing populism and extremism (Flecker, 2007: 245).

In this article, we have suggested that individual-level emotional responses mediate between macro-level sociocultural and economic changes, such as globalization, modernization, and economic deregulation, and the micro-level motivation to support right- 
Emotional roots of right-wing political populism

wing populist parties. More precisely, we have identified two emotional mechanisms. The first mechanism relates to ressentiment and explains how negative emotions - in particular fear and insecurity - experienced in post-industrial societies can transmute through repressed shame into anger, resentment, and hatred towards perceived "enemies" of the self, such as immigrants, refugees, the unemployed, and political and cultural elites. The second mechanism relates to emotional distancing from social identities that frequently evoke shame and other negative emotions in favor of social identities that are perceived to be more stable and to some extent more exclusive, such as nationality, ethnicity, language, religion, and traditional gender roles.

We propose that these mechanisms contribute to the existing literature on third-wave rightwing populism. Much of this literature has focused on cultural, social structural, and economic preconditions of right-wing populist support and has successfully identified constellations that are supportive of the flourishing of right-wing parties. This pertains to societal conditions (for example economic deregulation) as well as to individual level characteristics (e.g., educational attainment, income). The importance of emotions features mostly implicitly in these existing works, for example in showing that certain sociodemographic characteristics are systematically linked to unfavorable attitudes and stereotypes toward those usually portrayed by right-wing populists as belonging to an outgroup rather than to the in-group, for instance, refugees, immigrants, ethnic minorities, or the unemployed. Whereas attitudes and stereotypes are widely understood to involve affective or emotional components in a rather general sense, our proposed mechanisms relate to a number of specific emotions and their associations with social identities in explaining right-wing populist support.

Although decidedly theoretical in nature, our paper strongly draws on existing evidence and should also pave the way to empirically investigate our propositions. The argument outlined in this contribution suggests a number of testable hypotheses that pertain to associations between the experience of specific emotions, sociodemographic indicators, voting behavior, and participation in right-wing political and social movements. Admittedly, the more causal transformative mechanism we suggest might be difficult to pin down, but longitudinal data could prove useful in approximating the effects we assume. Also, in-depth interviews might 
Emotional roots of right-wing political populism

contribute to revealing the emotional experiences that are associated with support for rightwing populist parties, although participants openly supporting these parties are difficult to recruit. Finally, comparative studies may directly address some of the implied differences between support for right- and left-wing populist parties as well as differences between parties of either sort in different countries.

From our perspective, a key question is how societies can and should deal with the negative emotions and feelings that motivate support for the new radical right. One obvious way, as suggested by Flecker in the quote above, is to address the structural conditions under which people tend to experience those emotions. Changes to the present social structural conditions might in fact attenuate these emotions. However, such changes would be likely to elicit equally politicized emotions in other social groups, depending on political preferences and ideological leaning. Certainly, there is a need to reduce rising social inequalities, and the excessive neoliberal policies driving these inequalities can be questioned on solid grounds. But history teaches us that -- contrary to some of the classics' suggestions that "rationalization" (Weber, 1930) or "affective neutrality" (Parsons, 1951) are cornerstones of the modern world -- societies are essentially characterized by the emotions that citizens experience vis-a-vis culture and social structure (e.g., Frevert, 2011; Reddy, 2001). And more often than not, these emotions are politicized, and they reflect or create antagonisms between different groups, such as social classes, religious communities, or political ideologies.

Societies need to accept and come to terms with the fact that inasmuch as they become more diverse and more plural in the wake of globalization and transnationalization, they will become more fragmented in terms of the citizens' political feelings and emotions. Hence, because people usually do not choose their emotions, it makes little sense to discredit and pathologize citizens' political emotions, no matter whether left or right. Instead, there needs to be a public debate on how societies can not only endure, but effectively address the divergent and possibly antagonistic emotions of their citizens. This endeavor would be closely related to the multiculturalism debates that address diversity at the level of cultural values, beliefs, practices, and, more recently, also affect and emotion (e.g., Mahmood, 2009) 
Emotional roots of right-wing political populism

as well as to concepts of the social and the political that emphasize dissent and antagonism, as for instance Mouffe's (2005) "agonistic pluralism".

This is not to say, of course, that societies should be let to fall prey to citizens' emotional upheavals. In particular, politicians, public commentators, journalists, entrepreneurs, academics and others with the potential to "voice" need to uncover and dismantle the discursive strategies of populist political emotionalization, mobilization, and boundary making, no matter left or right. This can only be achieved through constant debate and exchange, through fact checking, and through inclusive rather than exclusionary rhetorics. 
Emotional roots of right-wing political populism

\section{Acknowledgements}

The authors would like to thank Montserrat Guibernau, Jonathan Heaney, Katariina Mäkinen, Gavin Sullivan, and the anonymous reviewers of this article for valuable comments and suggestions on its earlier versions. The first author would also like to thank Tuuli Lähdesmäki, Karl Malmqvist, Cristian Norocel, Johanna Sumiala, and several commentators at Cultural and Rhetorical Aspects of Political Populism conference, University of Jyväskylä, on October 24-25, 2014; Moral and Political Philosophy seminar, University of Helsinki, on November 5, 2014; Thumos Seminar at the Department of Philosophy, University of Geneva, on November 27, 2014; and Swiss Sociological Association annual conference, University of Lausanne, on June 3-5, 2015.

\section{$\underline{\text { References }}$}

Ahmed S (2004) Affective economies. Social Text 22: 117-139.

Arzheimer K (2009) Protest, neo-liberalism or anti-immigrant sentiment: What motivates the voters of the extreme right in Western Europe? Zeitschrift für Vergleichende Politikwissenschaft 2: 173-197.

Barbalet J (1998) Emotion, Social Theory, and Social Structure. Cambridge: Cambridge University Press.

Barbalet J and Demertzis N (2013) Collective fear and societal change. In: Demertzis N (ed) Emotions in Politics. Basingstoke: Palgrave Macmillan, pp.166-185.

Baumgarten B (2013) Geração à Rasca and beyond: Mobilizations in Portugal after 12 March 2011. Current Sociology 61(4): 457-473.

Bröckling U (2016) The Entrepreneurial Self. London: Sage.

Bauman Z (1998) Work, Consumerism, and the New Poor. Buckingham: Open University Press. 
Emotional roots of right-wing political populism

Bauman Z (2000) Globalization. Cambridge: Polity Press.

Bauman Z (2001) The Individualized Society. Cambridge: Polity Press.

Beck U (2000) The Brave New World of Work. Cambridge: Polity Press.

Ben-Ze'ev A (2000) The Subtlety of Emotions. Cambridge, MA: The MIT Press.

Benski, T and Langman, L (2013) The effects of affects: The place of emotions in the mobilizations of 2011. Current Sociology 61(4): 525-540.

Berezin M (2009) Illberal Politics in Neoliberal Times. Cambridge: Cambridge University Press.

Berlant L (2011) Cruel Optimism. Durham and London: Duke University Press.

Betz HG (1994) Radical Right-Wing Populism in Western Europe. London: Macmillan.

Betz HG (2005) Against the system: radical right-wing populism's challenge to liberal democracy. In: Rydgren J (ed) Movements of Exclusion: Radical Right-Wing Populism in the Western world. Hauppauge, NY: Nova Science Publishers, pp.25-40.

Calhoun C (2004) An apology for moral shame. Journal of Political Philosophy 11: 1-20.

Cast A and Burke P (2002) A theory of self-esteem. Social Forces 80: 1041-1068.

Clark A, Diener E, Georgellis Y, Lucas R E (2008) Lags And Leads in Life Satisfaction: a Test of the Baseline Hypothesis. The Economic Journal, 118(529): F222-F243.

Clarke J and Newman J (2012) The alchemy of austerity. Critical Social Policy 32: 299319.

Clore G and Gasper K (1999) Feeling is believing: some affective influences on thought. In: Frijda N, Manstead A and Bem S (eds) Emotions and Beliefs. How Feelings Influence Thoughts. Cambridge: Cambridge University Press, pp.10-44.

Cooley CH (1964 [1922]) Human Nature and the Social Order. New York: Schocken Books. 
Emotional roots of right-wing political populism

Davou B and Demertzis N. (2013) Feeling the Greek financial crisis. In: Demertzis, N (ed) Emotions in Politics. Basingstoke: Palgrave, pp. 93-123.

della Porta D (2015) Social Movements in Times of Austerity. Cambridge: Polity Press.

De Weerdt Y, Catellani P and De Witte H et al. (2007) Perceived socio-economic change and right-wing extremism: results of the SIREN-survey among European workers. In: Flecker $\mathrm{J}$ (ed) Changing Working Life and the Appeal of the Extreme Right. Aldershot: Ashgate, pp.63-83.

Demertzis N (2006) Emotions and populism. In Clarke S, Hoggett P, and Thompson S (eds) Emotions, Politics and Society. London: Palgrave Macmillan, pp. 103-122.

Densley JA (2013) How Gangs Work: An Ethnography of Youth Violence. Basingstoke: Palgrave Macmillan.

Deanna J, Rodogno R and Teroni F (2012) In Defense of Shame. Oxford: Oxford University Press.

Douglas T (1995) Scapegoats: Transferring Blame. London: Routledge.

Eatwell R (2003) Ten theories of extreme right. In: MerkI PH and Weinberg L (eds) RightWing Extremism in the Twenty-First Century. London: Frank Cass, pp.47-73. Fessler DMT (2007) From appeasement to conformity: evolutionary and cultural perspectives on shame, competition, and cooperation. In: Tracy JL, Robins RW, Tangney JP (eds) The Self-Conscious Emotions. Theory and Research. New York: The Guilford Press, pp.174-193.

Flecker J (2007) Conclusions and policy implementations. In: Flecker J (ed) Changing Working Life and the Appeal of the Extreme Right. Aldershot: Ashgate, pp.239-249.

Flecker J, Hentges G and Balazs G (2007) Potentials of political subjectivity and the various approaches to the extreme right: findings of the qualitative research. In: Flecker J (ed) 
Emotional roots of right-wing political populism

Changing Working Life and the Appeal of the Extreme Right. Aldershot: Ashgate, pp.35-

62.

Flesher Fominaya C (2014) Social Movements and Globalization: How Protests, Occupations and Uprisings are Changing the World. London: Palgrave Macmillan.

Frevert U (2011) Emotions in history - Lost and found. Budapest: Central European University Press.

Furedi F (2007) Invitation to Terror: The Expanding Empire of the Unknown. London: Continuum.

Goffman E (1963) Stigma. London: Penguin.

Golder M (2003) Explaining variation in the success of extreme right parties in Europe. Comparative Political Studies 36(4): 432-466.

Golec de Zavala A, Cichocka A and Eidelson R et al. (2009) Collective narcissism and its social consequences. Journal of Personality and Social Psychology 97: 1074-1096.

Guibernau M (2010) Migration and the rise of the radical right. Policy Network, 1-19.

Guibernau M (2013) Belonging. Solidarity and Division in Modern Societies. Cambridge: The Polity Press.

Hoelter JW (1986) The relationship between specific and global evaluations of self: a comparison of several models. Social Psychology Quarterly 49: 129-141.

Ignazi P (2003) The development of the extreme right at the end of the century. In: Merkl PH and Weinberg L (eds) Right-Wing Extremism in the Twenty-First Century. London: Frank Cass, pp.143-158.

Illouz E (2007) Cold Intimacies. The Making of Emotional Capitalism. London: Polity Press. Jasper JM (2014) Constructing indignation. Anger dynamics in protest movements. Emotion Review 6(3): 208-213. 
Emotional roots of right-wing political populism

Juntunen I (2014) Ken ei työtä tee, sen ei syömänkään pidä. Työttömyys kulttuurisena marginaalina ja siihen liittyvät neuvottelut. Master's Thesis, Department of Social Research, University of Helsinki.

Kinnvall C (2013) Trauma and the politics of fear: Europe at the crossroads. In: Demertzis N (ed) Emotions in Politics. Basingstoke: Palgrave Macmillan, pp. 143-166.

Kriesi $H$ (1999) Movements of the left, movements of the right: putting the mobilization of two new types of social movements into political context. In: Kitschelt $\mathrm{H}$, Lange $\mathrm{P}$ and Marks $\mathrm{G}$ et al. (eds) Continuity and Change in Contemporary Capitalism. Cambridge: Cambridge University Press, pp.398-423.

Laclau E (2005) On Populist Reason. London: Verso.

Lane C M (2011) A Company of One: Insecurity, Independence, and the New World of WhiteCollar Unemployment. Ithaca, NY: Cornell University Press.

Lewis H (1971) Shame and Guilt in Neurosis. New York: International Universities Press. Lewis M (1995) Shame: The Exposed Self. New York: Free Press. Lipset SM (1963) Political Man. Garden City, NY: Anchor Books. Lubbers M and Scheepers P (2001) Explaining the trend in extreme right-wing voting. Germany 1989-1998. European Sociological Review 17(4): 432-449.

Lubbers M, Gijsberts M and Scheepers P (2002) Extreme right-wing voting in Western Europe. European Journal of Political Research 41(3): 345-378.

Lubbers M, Scheepers P and Billiet J (2000) Multilevel modeling of Vlaams Blok voting. Acta Politica 35(4): 363-398.

Mahmood S (2009) Religious Reason and Secular Affect: An Incommensurable Divide? Critical Inquiry 35(4): 836-862.

Mäkinen K (2012) Becoming Valuable Selves. Tampere: University of Tampere. 
Emotional roots of right-wing political populism

Mäkinen K (2013) Rajoja ja säröjä: talous maahanmuuttovastaisessa keskustelussa.

Poliittinen talous 1(1) http://poliittinentalous.fi/ojs/index.php/poltal/article/view/2/2

Mäkinen K (2016) Struggles of citizenship and class. Sociological Review. An e-

publication ahead of print. DOI: 10.1111/1467-954X.12392.

Malmqvist K (2014) Repressing empathy, expressing contempt, enjoying superiority. On the orderliness of emotional articulation in online racist discourse targeting migrant panhandlers in Sweden. In: European Sociological Association, Sociology of Emotions, Mid-term conference, University of Rhodes, Greece, 25-27 September 2014.

Marsdal ME (2013) Loud values, muffled interests: Third Way social democracy and rightwing populism. In: Wodak R, Khosravinik M and Mral B (eds) Right-wing Populism in Europe: Politics and Discourse. London: Bloomsbury, pp.39-54.

Mau S (2015) Inequality, Marketization and the Majority Class. Basingstoke: Palgrave.

Meltzer BN and Musolf GR (2002) Resentment and ressentiment. Sociological Inquiry 72: 240-255.

Merton RK (1963) Social Theory and Social Structure. New York: Free Press.

Miceli M and Castelfranchi C (2015) Expectancy and Emotion. Oxford: Oxford University Press.

Mileti FP \& Plomb F (2007) Addressing the link between socio-economic change and rightwing populism and extremism: a critical review of the European literature. In: Flecker J (ed) Changing Working Life and the Appeal of the Extreme Right. Aldershot: Ashgate, pp. $9-34$.

Minkenberg M (2000) Renewal of the radical right: between modernity and anti-modernity. Government and Opposition 35: 170-188. 
Emotional roots of right-wing political populism

Mols F and Jetten J (2014) No guts, no glory: How framing the collective past paves the way for anti-immigrant sentiments. International Journal of Intercultural Relations 43: 74-86.

Moons WG, Leonard DJ and Mackie DM et al. (2009) I feel our pain: Antecedents and consequences of emotional self-stereotyping. Journal of Experimental Social Psychology 45: 760-769.

Mouffe C (2005) On the Political. New York: Routledge.

Mudde C (2007) Populist Radical Right Parties in Europe. Cambridge: Cambridge University Press.

Neckel S (1991) Status und Scham: zur symbolischen Reproduktion sozialer Ungleichheit. Frankfurt am Main: Campus.

Newman K S (1998) Falling From Grace: Downward Mobility In The Age Of Affluence. New York: Free Press.

Norocel OC (2013) "Give us back Sweden!" A feminist reading of the (re)interpretations of the Folkhem conceptual metaphor in Swedish radical right populist discourse. NORA Nordic Journal of Feminist and Gender Research 21(1): 4-20.

Norris P (2005) Radical right. Voters and parties in electoral market. Cambridge: Cambridge University Press.

O'Malley E, Fitzgibbon J (2015) Everywhere and nowhere: Populism and the puzzling nonreaction to Ireland's crises. In: Kriesi H and Pappas TS (eds) European Populism in the Shadow of the Great Recession. Colchester: ECPR Press, pp. 287-302.

Parsons T (1951) The Social System. New York: Free Press.

Perugorria I and Tejerina B (2013) Politics of the encounter: Cognition, emotions, and networks in the Spanish 15M. Current Sociology 61(4): 424-442. 
Emotional roots of right-wing political populism

Rackow K, Schupp J and von Scheve C (2012) Angst und Ärger. Zur Relevanz emotionaler

Dimensionen sozialer Ungleichheit. Zeitschrift für Soziologie 41(5): 391-409.

Rawls J (1971) A Theory of Justice. Oxford: Clarendon Press.

Reddy W (2001) The Navigation of Feeling. Cambridge: Cambridge University Press.

Richards B (2013) Extreme nationalism and the hatred of the liberal state. In: Demertzis N

(ed) Emotions in Politics. Basingstoke: Palgrave Macmillan, pp.124-142.

Sakki I and Pettersson K (2015) Discursive constructions of Otherness in populist right political blogs. European Journal of Social Psychology. DOI: 10.1002/ejsp.2142.

Scheff TJ (1994) Bloody Revenge. Emotions, Nationalism, and War. Lincoln: Authors Guild.

Scheff TJ (2000) Shame and the social bond: A sociological theory. Sociological Theory 84:

84-99.

Scheff TJ and Retzinger SM (2000) Shame as the master emotion of everyday life. Journal of Mundane Behavior 1(3): 303-324.

Scheler M (1994 [1915]) Ressentiment. Translation by Coser LB and Holdheim WW. Introduction by Frings MS. Milwaukee, WI: Marquette University Press.

Sennett R (1998) The Corrosion of Character. New York and London: WW Norton.

Smith ER and Mackie DM (2015) Dynamics of group-based emotions: Insights from intergroup emotions theory. Emotion Review 7(4): 349-354.

Sotirakopoulos, N and Sotiropoulos G (2013) Direct democracy now!': The Greek indignados and the present cycle of struggles. Current Sociology 61(4): 443-456.

Starrin B (2013) Stigma, skam, och fattigdom. In: Karlsson LB, Kuusela K and Rantakeisu U (eds) Utsatthet, marginalisering, och utanförskap. Lund: Studentlitteratur, pp.75-95. Strawson PF (1974) Freedom and Resentment and Other Essays. London: Methuen \& Co Ltd. 
Emotional roots of right-wing political populism

Sullivan GB (2014) Collective pride and collective arrogance in organizations. In: Sullivan GB (ed) Understanding Collective Pride and Group Identity. New directions in emotion theory, research, and practice. London: Routledge, pp.80-92.

Swank D and Betz HG (2003) Globalization, the welfare state, and right-wing populism in Western Europe. Socio-Economic Review 1: 215-245.

Tangney JP and Dearing RL (2002) Shame and Guilt. New York: Guilford Press.

Tracy JL and Robins RW (2004) Putting the self into self-conscious emotions: a theoretical model. Psychological Inquiry 15: 103-125.

Tracy JL and Robins RW (2007) The psychological structure of pride: a tale of two facets. Journal of Personality and Social Psychology 92: 506-525.

Turner JH (2007) Self, emotions, and extreme violence: extending symbolic interactionist theorizing. Symbolic Interaction 30: 501-530.

Van Stekelenburg J and Klandermans B (2007) Individuals in movements: A social psychology of contention. In: Klandermans B and Roggeband CM (eds) The Handbook of Social Movements across Disciplines. New York: Springer, pp.157-204.

Van Zomeren M, Spears R and Fischer AH et al. (2004) Put your money where your mouth is! Explaining collective action tendencies through group-based anger and group efficacy. Journal of Personality and Social Psychology 87(5): 649-664.

Vares V and Railo E (2011) Oikeistopopulismin monet kasvot: perussuomalaisuus poliittisen historian ja mediatutkimuksen näkökulmasta. Helsinki: Center for European Studies/Suomen Toivo-ajatuspaja.

von Beyme K (1988) Right-wing extremism in post-war Europe. In: Von Beyme K (ed) RightWing Extremism in Western Europe. London: Frank Cass, pp.1-18. 
Emotional roots of right-wing political populism

von Scheve C (2015) Societal origins of values and evaluative feelings. In: Brosch T and

Sander D (eds) The Handbook of Value: Perspectives from Economics, Neuroscience,

Philosophy, Psychology and Sociology. New York: Oxford University Press, pp.175-195.

von Scheve C, Zink V and Ismer S (2014) The blame game: economic crisis responsibility,

discourse and affective framings. Sociology. Epub ahead of print. DOI:

$10.1177 / 0038038514545145$.

Wacquant L (2010) Crafting the Neoliberal state: workfare, prisonfare, and social insecurity.

Sociological Forum 25: 197-220.

Walker R (2014) The Shame of Poverty. New York: Oxford University Press.

Weber M (1939) The Protestant Ethic and the Spirit of Capitalism. London: Allen and Unwin.

Werts H, Scheepers P and Lubbers M (2012) Euro-scepticism and radical right-wing voting in

Europe, 2002-2008: Social cleavages, socio-political attitudes and contextual

characteristics determining voting for the radical right. European Union Politics 14(2):

183-205.

Wodak R (2015) The Politics of Fear. What Right-Wing Populist Discourses Mean. London: SAGE publications.

Wodak R and Forchtner B (2014) Embattled Vienna 1683/2010: Right-wing populism, collective memory and the fictionalization of politics. Visual Communication 13: 231255.

Wodak R, Khosravinik M and Mral B (eds.) (2013) Right-Wing Populism in Europe: Politics and Discourse. London: Bloomsbury.

Wollheim R (1999) On the Emotions. New Haven: Yale University Press.

Zahavi D (2012) Self, consciousness, and shame. In: Zahavi D (ed) The Oxford Handbook of Contemporary Phenomenology. Oxford: Oxford University Press, pp.304-323. 